\title{
THE EFFECT OF TRUST TO GOVERNMENT, MORAL OBLIGATION AND COMPLIANCE COSTS ON TAXPAYERS COMPLIANCE BEHAVIOR
}

\author{
Muslichah \\ STIE Malangkucecwara \\ Jln. Candi Kalasan Malang \\ E-mail: muslihchahmachali@yahoo.com
}

HP. 0816553941

\begin{abstract}
The aim of this study is to examine the direct and indirect effect of trust to government, costs of compliance and moral obligation on taxpayer compliance behavior. This study was conducted in East Java. The respondents of the study are business taxpayers. Fourty three taxpayers participated in this study. The findings of this study show that: (1) the direct effect trust to government on taxpayer compliance behavior is positive and significant (2) the indirect effect of trust to government on taxpayer compliance behavior through moral obligation is positive and significant (3) the indirect effect of trust to government on taxpayer compliance behavior through costs of compliance is insignificant. This study contribute not only to the research literature but also to help government to develop strategies toward improving compliance.
\end{abstract}

Keywords: trust to government, moral obligation, compliance costs, compliance behavior.

Indonesia uses a self assessed taxing system that relies on voluntary compliance by taxpayers. In other words taxpayers should calculate, pay and report the amount of tax liability by themselves. Nowadays, scholars and policymakers worldwide are interested in how to mitigate tax evasion and maximize compliance with the tax laws. Since individual income taxes are the major source of revenue for a government, non compliance has a significant economic impact. Tackling of the policy problem of tax 
evasion requires some understanding of the factors underlying the individual's decision to pay or evade his taxes.

Concern about the deterioration in voluntary tax compliance has produced a myriad of research (For review, see Schadewald, 1989; Nam et al., 2002; Hite and Hasseldine, 2003; Bobek and Hatfield, 2003). Previous researchers have examined how individual compliance is affected by age (Tittle, 1980; Grasmick et al., 1984), Sex (Minor, 1978; Grasmick and Scott, 1980), income source (Madeo et al., 1985), occupation (Mason and Calvin, 1978; Westat, 1980), fairness (Yankelovich et al. 1984; Etzioni, 1986), complexity (Sanders and Wyndelts, 1989; Magro, 1999; Spilker et al., 1999), tax rates (Mason and Calvin, 1984; Keller, 1998), tax compliance costs (Nam, 2002), audit adjustments (Chan and Mo, 2002) and moral obligation (Bobek and Hatfield, 2003).

Despite those researches, most behavioral studies have not incorporated trust to government in their models for predicting compliance behavior. It is argued that the trust to government has a possibility to directly influence taxpayer compliance behavior, or indirectly through moral obligation and costs of compliance. For many years, trust have been discussed as a variable that crucial for organizational effectiveness (Gomez and Rosen, 2001). Trust is at the heart or organizational coordination and control (Mc Allister, 1995). Trust means a positive expectation that another (through words, actions, or decisions) will not act opportunistically (Robbins, 2001:336). Furthermore, when taxpayers trust a leader, they are willing to be vulnerable to the leader's actions, confident that their rights and interests will not be abused (Hosmer, 1995; Mayer et al., 1995). The willingness of government to create mutually trusting relationships is a matter of strategic choice. That is, goverment can create benefits of trust in long term period, including the attainment of tax target every year which is ultimately enhance governmental capacities. Taxpayers can trust the government when they know and understand the goals of the government. When there is a hidden agenda, there is no trust. In other words trust is the key to success for the government to acquire taxpayers compliance. Trust promoting positive attitude toward government, and ultimately increase compliance behavior.

Trust is intangible entity, it is difficult to grasp but powerful in its ability to influence the success of government program in a variety forms. In a successful 
government program, trust is the basic foundation that can create widespread moral obligation. Several studies have investigated the relationship between trust to government and moral obligation (Beck and Ajzen ,1991; Kaplan et al., 1997; Reckers et al., 1994; Bobek and Hatfield, 2003). Beck and Ajzen (1991) found that adding a measure of moral obligation increased the predictive power of their model when explaining college students' cheating and lying behaviors. Kaplan et al. (1997) found that an individual's level of moral development is significantly correlated with compliance and also influences the effectiveness of certain educational communications to improve compliance. Etzioni (1986) argue that moral obligation are an important factors underlying taxpayer behavior and that the variable may be more effective than the other factors in inducing compliance. The importance of moral obligation is reinforced by a field experimental research undertaken in the united states indicates that moral obligation play an important role in affecting tax compliance and tax evasion decision (Reckers et al., 1994; Bobek and Hatfield, 2003).Thus, feeling of trust could create sense of moral obligation, and increasing moral obligation leads to better and positive attitude toward tax

Beside influence moral obligation, trust to government also identified to have an impact on costs of compliance. Costs of compliance here is defined as costs associated with the number of hours spent in preparing tax, administrative expenses, and any money spent on the procurement of the services of tax professionals. Frank (1988) and Jones (1995) stated that trust lower agency and transaction costs. The increase feeling of trust will improve taxpayers commitment to obey tax regulation by preparing records, hiring professionals. By trusting the government, taxpayers do not require to make "double records" and spend "double expenses" related to their transactions. Thus, trust to government will decrease costs of compliance, the increase costs of compliance among taxpayers will ultimately increase compliance behavior.

The purpose of this study is to examine whether trust to government improve compliance behavior through moral obligation and costs of compliance. A model is proposed in which moral obligation and costs of compliance mediate the relation between trust to government and compliance behavior. This study is an extension of previous studies, the important thing that differentiate the study with the others are the 
direct effect of costs of compliance and moral obligation on compliance behavior have been examined by previous researchers. This study extended their research by investigating the indirect effect of trust to government on taxpayer compliance behavior through moral obligation and costs of compliance.

\section{HYPOTHESES DEVELOPMENT}

\section{Linkage Between Trust to Government and Compliance Behavior}

For many years, trust has been discussed as a variable that is cruicial for organizational effectiveness. A recent explosion of interest in trust has generated a large and rapidly expanding body of literature, demonstrating trust's importance to economic life (Wicks et al., 1999). Trust helps facilitate cooperation (Mayer et al., 1995; Smith et al., 1995), lowers agency and transaction costs (Jones, 1995), promotes smooth and efficient market exchanges (Smith, 1981), and improves firms' ability to adapt to complexity and change (Koorsgard et al., 1996). There are five dimensions that underlie the concept of trust, they are integrity, competence, consistency, loyalty, and openness. (Robbins, 2001). Integrity refers to honesty and truthfulness. Competence encompass an individual's technical and interpersonal knowledge and skills. Consistency relates to an individual's reliability, predictability, and good judgment in handling situations. Inconsistencies between words and action decrease trust. Loyalty is the willingness to protect and save face for another person. Trust requires that you can depend on someone not act opportustically. The final dimension of trust is openness which means telling the full truth.

Trust is believed to play an important role in the relationship that government has with his taxpayers. Taxpayers may to develop higher level of trust with the government if they believe that such trust may create significant benefit. Spicer and Lundstedt (1976) and Smith (1992) hypothesize that a taxpayer will feel "cheated" if he believes that his tax dollars are not well spent, and may reciprocate by refusing to pay his full tax liability. Jackson and Mckee (1992) perform experiments to test this idea. They find a greater willingness to comply when participants perceive that they will receive benefits from public good funded by the taxes collected.

If taxpayers do not know how the the government use the taxes levied from them, they cannot evaluate whether the government used the taxes for interest of their 
country. Tax expenditures must be analyzed and integrated into the budgetary process to ensure fiscal accountability. In addition, tax expenditures must be audited for performance and the information must be published (with comprehensive analysis) to ensure fiscal transparency. Providing taxpayers information about tax expenditures would result in broader consensus on government tax system. Thus, the increase trust to government will increase compliance behavior. This idea is formally expressed in the hypothesis:

H1: There is a direct effect of trust to government on compliance behavior

\section{Linkage Among Trust to Government, Moral Obligation and Compliance Behavior}

It is evident that the willingness of government to create mutually trusting relationships is a matter of strategic choice. Trust defined as mutual confidence that no party to an exchange will exploit another's vulnerabilities (Barney and Hansen, 1994). Trust to Government will increase the feeling that avoiding to pay tax is not morally right or wrong decision. Trust is a positive expectation that another will not - through words, actions or decisions - act opportunistically (Robbins, 2001) The term opportunistically refers to the inherent risk and vulnerability in any trusting relationship. Trust involves making oneself vulnerable as when, for example we rely on anothers's promises. Trust to government is believed will increase moral obligation through internalizing ethical values.

Moral (or sometimes called morality) come form latin language mos mores which means customs or traditions (Tridiatno,2000). Moral also defined in a broader way that is about bad - good of human being. Someone called has good morality if he follow good values or norms. On the other hand, someone called has bad or evil morality because he acts to follow bad values or norms. Djakfar (2007) states that moral has the same meaning with "akhlak", the meaning stress that in moral definitions also attach religion values. Moral (or morality) initially come from individual customs or traditions, then be generalized. Etzioni (1988) states that moral values do not intrude or twist rational deliberations; rather, moral values render some decision making more effective and efficient. Moral values values affect the decision process by screening or 
setting bounds on choice possibilities and limiting the means available to achieve desired outcomes. To the extent that moral values limit choice, they reduce the cognitive effort in information searches, the identification of alternative choices, and the selection among choice (Carroll, 1987). Those alternatives that are not morally acceptable are unlikely to be consciously considered or selected (Reckers et al., 1994). The majority of studies reviewed on the relationship between moral and taxpayer compliance genenerally found that higher levels of individual morals are associated with greater taxpayer compliance. However, Jackson and Milliron (1986) noted that the significance of the relationship between moral and compliance tended to vary depending on the particular definition of moral adopted.

Thus, taxpayer morals play a crucial role in the compliance decision by controlling taxpayer behavior. When tax evasion is seen as a moral issue, individuals are less likely to evade taxes regardless of the tax situation. If taxpayers believe that the government will use tax money for the sake of the public, not corrupted for the "other interests", they will see that paying tax as a moral issue. It is bad decision (bad ahklak) if they don't pay tax liability and comply with tax regulation. These arguments lead to the following hypothesis:

$\mathrm{H} 2$ : There is an indirect effect of trust to government on compliance behavior through moral obligation

\section{Linkage Among Trust to Government, Compliance Costs and Compliance Behavior}

Taxation compliance costs can be defined as "the costs incurred by taxpayers and third parties in meeting the requirements laid upon them in complying with a given structure and level of tax". They include the costs incurred by individuals of acquiring sufficient knowledge to meet their legal obligations, the costs of compiling the necessary receipts and other records, and of completing tax; payments to professionals taxation advisers and preparers; and incidental costs for postage, telephone, and travel in order to communicate with advisers or the tax authorities. For businesses, compliance costs include the cost of collecting, paying, and accounting for tax on products or profits of the enterprise, and on the wages and salaries of employees, together with the costs of 
acquiring the knowledge to enable this work to be done. Thus, The "classic" elements of compliance costs have been included: the cost of learning about the tax, keeping records, dealing with tax auditors, resolving misunderstandings with the tax authorities, etc.

Trust is believed to play an important role in the quality relationships that government has with their taxpayers. The successful of the government to achieve tax target my depend in large part on taxpayers' belief that government can be trusted. Feeling of trust are communicated through the disclosure of accurate and relevant information, the acceptance of another's influence and recognition of interdependence (Zand, 1972). Trust to government can be build by giving tax fund flow transparency, how much money collected from tax and how the money is used. Trust is the basic foundation that can create widespread commitment (Korsgaard et al., 1995).

Thus, increasing taxpayers trust to government will cause the decrease in costs of compliance. Trust to government will encourage taxpayers to make "good recording" according to government law and avoid to make "double recording and reporting". In Indonesia it is happened in some companies to avoid tax by making double recodrs or reports, one (a right one) for the internal and another one (wrong one) for the external (Government/tax autority). Variables such as trust needed to be considered when managing non compliance. If regulators are seen to be acting fairly, people will commit the motives of the authority, and will deter to their decisions voluntarily. Thus the following hypothesis is suggested:

H3 There is an indirect effect of trust to government on compliance behavior through costs of compliance

Based on the arguments developed above, the model below could be constructed: 


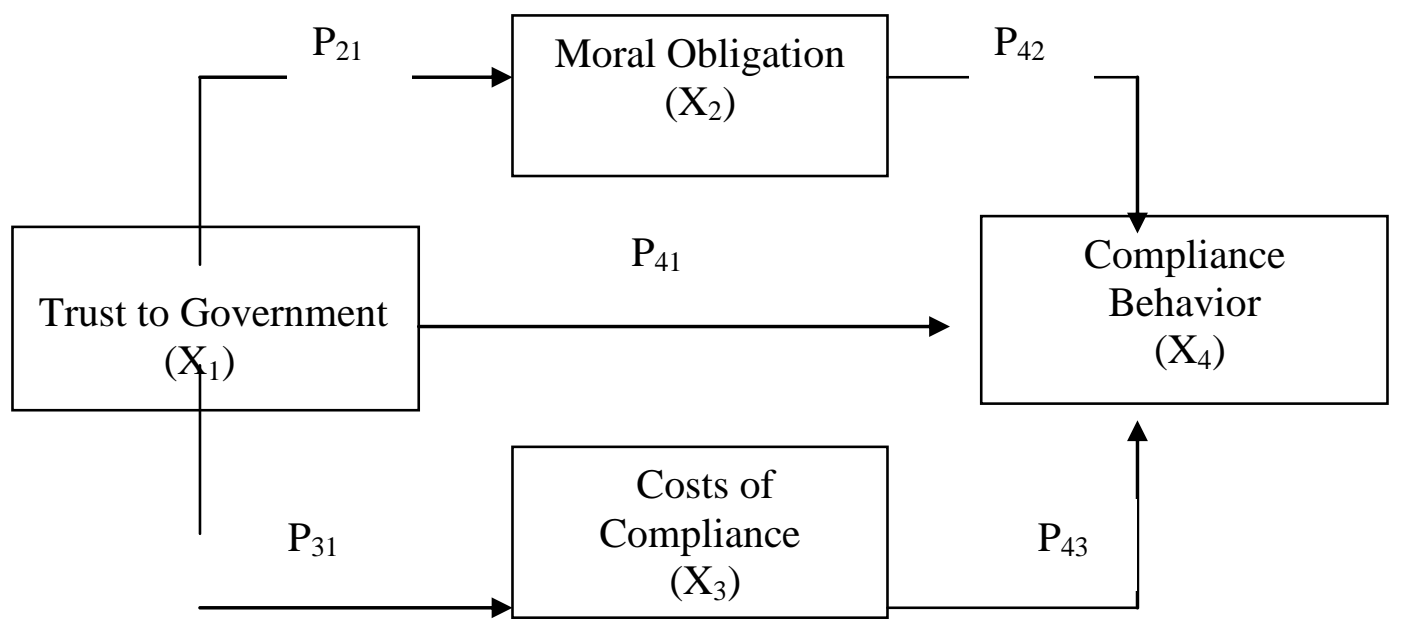

Figure 1

The Model of The Present Study

\section{RESEARCH METHOD}

\section{Data and Sample}

This study was conducted in Malang. Data for this study were collected using a questionnaire to business taxpayers in three different type of industries: service, manufacturing and merchandising. A total of 100 questionnaires were sent and 51 were returned, making a response rate $51 \%$. From the total questionnaire, 8 were excluded from the study for incomplete responses, invalidity and irreliability matters. This left the study with 43 usable questionnaires for data analysis. Besides, the data are not collected randomly because of the difficulty of of determining population of this study, especially related the determination of what individuals have significant impact on tax decisions. In several companies the owner and chief executive (often the same individual) acts as the brain of the organization and is the key determinant of tax decision. But in the other companies, there are many stockholders which one of them responsible to make a decision relates to tax. To overcome the difficulty, the author using key informant approach that inform about the targeted respondents. Tabel 1 below provide demographic data collected from the respondents which encompass type of business, gender, age, last formal education and educational background. 
Table 1

Demographic Data of The Respondents

\begin{tabular}{|c|c|c|}
\hline Variable & $\begin{array}{c}\text { No. } \\
\text { Respondents }\end{array}$ & Percentage \\
\hline \multicolumn{3}{|l|}{ Type of Business } \\
\hline - Service & 14 & 32,56 \\
\hline - $\quad$ Manufacturing & 21 & 48,84 \\
\hline - Merchandising & 8 & 18,60 \\
\hline \multicolumn{3}{|l|}{ Age } \\
\hline \multicolumn{3}{|l|}{ - 20 or under } \\
\hline - 21 to 30 & 3 & 6,98 \\
\hline - 31 to 40 & 8 & 18,60 \\
\hline - Over 40 & 32 & 74,42 \\
\hline \multicolumn{3}{|l|}{ Gender } \\
\hline - $\quad$ Female & 6 & 13,95 \\
\hline - Male & 37 & 86,05 \\
\hline \multicolumn{3}{|l|}{ Educational background } \\
\hline - Economics & 22 & 51,16 \\
\hline - $\quad$ Engineering & 5 & 11,63 \\
\hline - Law & 7 & 16,28 \\
\hline - Others & 9 & 20,93 \\
\hline \multicolumn{3}{|l|}{ Last formal education } \\
\hline - Senior high school & 4 & 9,3 \\
\hline - Undergraduate & & \\
\hline - $\quad$ Postgraduate & 39 & 90,7 \\
\hline
\end{tabular}




\section{VARIABLE MEASUREMENT}

\section{Trust to Government}

Trust rests on the belief that government is competent, open, concerned and reliable (Butler, 1991; Mishra, 1993; Hosmer, 1995). Trust was measure using a 4 item Likert-type scale, an example of scale item is "I trust to the government that they will transparently declare revenue and uses of fund from tax". Taxpayer responded on a 5 point scale ranging from 1 (very low) to 5 (very high). A high numerical response a perception of high degree of trust while a low numerical response indicate a low degree of trust. Cronbach alpha for this scale was also very good $(0,960)$.

\section{Moral Obligation}

Moral Obligation in the present study is to reveal individual perception about tax evasion/noncompliance, whether those attitude is determined as morally right - not morally right, culturally acceptable - culturally unacceptable, fair - unfair. Moral Obligation is measured by 6 items modified from Cruz et al. (2000). A high score on this scale indicates high moral obligation while a low score would indicate low moral obligation. Taxpayer responded on a 5 point scale ranging from 1 (very disagree) to 5 (very agree). The cronbach alpha coefficient was 0,983 which indicated high internal reliability for the scale.

\section{Compliance Costs}

Compliance costs is costs of collecting, remitting and accounting for income tax on the income, together with the cost of acquiring the knowledge needed to enable this to be done efficiently. Compliance costs is`measured by six items and 5-point likert type. A high score on this scale indicates high costs of compliance while a low score would indicate low costs of compliance. The cronbach alpha coefficient was 0,950 which indicated high internal reliability for the scale.

\section{Taxpayer Compliance}

Taxpayer compliance is accurate, timely and fully paid return without government enforcement efforts. Five items were developed to measure taxpayer compliance. The items covered in this study consist of the accuracy to fill the tax form, the accuracy in 
calculating tax liability, timeliness, voluntary. Taxpayer responded on a 5 point scale ranging from 1 (strongly disagree to 5 (strongly agree). A high numerical response a perception of high degree of taxpayer compliance. The cronbach alpha coefficient was 0,917 which indicated high internal reliability for the scale.

\section{Analysis Models}

A path analytic technique was used to test the model of the study as shown in figure 1. This technique allows examination of the direct and indirect effect (Duncan, 1966; Alwin and hauser, 1975; Lewis - Beck, 1980). In the model, the relationships between variables were specified by a series of path coefficients $\left(\mathrm{P}_{\mathrm{ij}}\right)$ which are equivalent to standardized beta (B). The equation in the path model are shown as follows:

$$
\begin{aligned}
& X_{2}=P_{21} X_{1}+P_{2 a} R_{a} \\
& X_{3}=P_{31} X_{1}+P_{3 b} R_{b} \\
& X_{4}=P_{41} X_{1}+P_{42} X_{2}+P_{43} X_{3}+P_{4 c} R_{c}
\end{aligned}
$$

The first equation shows the trust to government $\left(X_{1}\right)$ as the independent variable and moral obligation $\left(\mathrm{X}_{2}\right)$ as dependent variable. The second equation treated costs of compliance $\left(X_{3}\right)$ as the dependent variable and trust to government $\left(X_{1}\right)$ as the independent variable. The third regression equation treated compliance behavior $\left(X_{4}\right)$ as the dependent variable and moral obligation $\left(X_{2}\right)$, trust to government $\left(X_{1}\right)$ and costs of compliance $\left(\mathrm{X}_{3}\right)$ as the independent variable.

Test on the adequacy of the regression models indicate that the assumptions of the models were satisfied by the data. Tests normality indicate that the results of each models are fairly normally distributed. To diagnose multicollinearity, the variance inflation factors (VIFs) are examined for the predictors. VIFs ranged from a low value of 1,000 to a high value of 1.189 . 


\section{RESEARCH FINDINGS}

As mentioned above, to test the three hypotheses developed in the present study, three regression equations were employed. The results of the equations are presented in table 2, 3 and 4

Table 2

Results of Regression of Equation 1

\begin{tabular}{|}
\begin{tabular}{|c|c|c|c|c|}
\hline \multicolumn{1}{|c|}{ Regression Results The Effect of Trust to Government $\left(\mathrm{X}_{1}\right)$ on Moral Obligation $\left(\mathrm{X}_{2}\right)$} \\
\hline Variable & Path coefficient & Coefficient value & T value & $\mathrm{P}$ \\
\hline $\mathrm{X}_{1}$ Trust to Govt & $\beta_{1}$ & 0.388 & 2.695 & 0.010 \\
\hline $\mathrm{R}^{2}=0.389 \quad \mathrm{~F}=7.329 \quad \mathrm{n}=43$ & $\alpha=5 \%$ \\
\hline
\end{tabular}
\end{tabular}

Table 3

Results of Regression of Equation 2

\begin{tabular}{|c|c|c|c|c|}
\hline \multicolumn{5}{|c|}{$\begin{array}{l}\text { Regression Results The Effect of Trust to Government }\left(\mathrm{X}_{1}\right) \text { on Costs of } \\
\text { Compliance }\left(\mathrm{X}_{3}\right)\end{array}$} \\
\hline Variable & Path coefficient & Coefficient value & $\mathrm{T}$ value & $\mathrm{P}$ \\
\hline $\mathrm{X}_{1}$ Trust to Govt & $\beta_{2}$ & 0.063 & 0.407 & 0.686 \\
\hline \multicolumn{5}{|c|}{$\mathrm{R}^{2}=0.004 \quad \mathrm{~F}=0,165 \quad \mathrm{n}=43 \quad \mathrm{a}=5 \%$} \\
\hline
\end{tabular}

Table 4

Results of Regression of Equation 3

\begin{tabular}{|l|c|c|c|c|}
\hline \multicolumn{6}{|c|}{ Regression Results The Effect of Trust to Government $\left(\mathrm{X}_{1}\right)$, Moral Obligation $\left(\mathrm{X}_{2}\right)$, } \\
Costs of Compliance $\left(\mathrm{X}_{3}\right)$ on Compliance Behavior $\left(\mathrm{X}_{4}\right)$ \\
\hline \multicolumn{6}{|c|}{ Variable } & Path coefficient & Coefficient value & T value & $\mathrm{P}$ \\
\hline $\mathrm{X}_{1}$ Trust to Govt & $\beta_{3}$ & 0.475 & 3.613 & 0.001 \\
$\mathrm{X}_{2}$ Moral Obligation & $\beta_{4}$ & 0.299 & 2.274 & 0.029 \\
$\mathrm{X}_{3}$ Costs of Compliance & $\beta_{5}$ & 0.069 & 0.569 & 0.573 \\
\hline $\mathrm{R}^{2}=0.432 \quad \mathrm{n}=9.907$ & $\mathrm{n}=43 \quad \mathrm{\alpha}=5 \%$ & \\
\hline
\end{tabular}




\section{Test of Hypothesis 1}

The first hypothesis of the model requires a test of the expected positive and significant relation between trust to government and taxpayer compliance. Table 5 presents the results to test hypothesis 1 . As shown in table 4 , the effect of trust to government on taxpayer compliance behavior is positive and significant $[\mathrm{p}(0,001)<$ 0,05]. Thus the results of the path model provide strong support for hypothesis 1 .

\section{Test of Hypothesis 2}

Hypothesis 2 states that there is an indirect effect of trust to government on compliance behavior through moral obligation. To test hypothesis 2, the results of regression 1 and 3 (table 2 and 4) are examined. The results presented in table 3 reveal the presence a positive and significant of direct effect between trust to government and moral obligation [p $(0,010)<0,05]$. Furthermore, according to the results of the third regression presented in table 5 that there is a positive and significant relationship [p $(0,029)<0,05$ ] between moral obligation and compliance behavior. These results lead author to conclude that the two path which form indirect effect of trust to government on compliance behavior through moral obligation are significant, therefore $\mathrm{H} 2$ could not be rejected.

\section{Test of Hypothesis 3}

It is expected in hypothesis 3 that there is indirect effect of trust to government on compliance behavior through costs of compliance. Table 3 and 4 provide the results to assess the indirect effect. Table 3 reveals that the effect of trust to government on costs of compliance is insignificant ( $\mathrm{p}=0,686>0,05)$. Table 4 also provides evidence to support hypotheses 3. Table 4 shows that the effect of trust to government on compliance behavior is also insignificant ( $\mathrm{p}=0,573>0,05)$. Thus it appears that the primary effect of trust to government on compliance behavior is not via costs of compliance, therefore $\mathrm{H} 3$ should be rejected

\section{Discussion, Conclusions, and Limitations}

The purpose of the present study is to examine empirically the mediating role of moral obligation and costs of compliance in the relationship between trust to 
government and compliance behavior. The results of this study add our understanding of the factors affecting compliance behavior. The findings of the present study contribute to tax compliance research by providing an explanation of the underlying causes of compliance. This study also provide results that indentify the "root causes" of non compliance to help government to develop strategies toward improving compliance. Thus this study has the potential not only to contribute to the research literature but also assist regulators (government) to make the effective tax law that could increase compliance behavior.

The results reveals that (1) the direct effect of trust to government on compliance behavior is significant (2) the indirect effect of trust to government on compliance behavior through moral obligation is positive and significant (3) the indirect effect of trust to government on compliance behavior through cost of compliance is insignificant. An explanation for the result of is that taxpayers tend to interpret trust to government as a powerful deterrent to noncompliance. As stated by Stonecipher (1998) that "nothing works without trust". Furthermore, the results also show that trust to government will increase individual moral beliefs in tax compliance decision. This findings indicate that moral beliefs are one of the screening factors that taxpayers use in the editing phase of decision making. Thus, taxpayers may edit out of the possibility choices all those that are not viewed as consistent with their moral duty (Bobek and Hatfield, 2003).

Contraty to expectations, the author did not find significant result on the indirect effect of trust to government on taxpayer compliance behavior through costs of compliance. An explanation for the result of is whether to avoid or obey the regulation, both require taxpayers to spend the money for keeping the records, other and "hidden" expenses to comply with the tax regulation. Beside this, in Indonesia there is widespread opinion that although taxpayers have already obeyed with the regulation, they still need "compromise mechanism" with tax officials.

This study had several limitations of which the future studies should be consider. First, the data of this study are not collected randomly, this reduce the generalising the results of this study. Second, the survey research methodology allows for the examination of statistical associations at one point in time, and the statements about the 
direction relationships can only be made in terms of consistency of results with the effects proposed in the theoretical discussion. Future research can employ different research methods, for example longitudinal field studies to systematically examine the theoretical causal relationships proposed in this study. We urge future researchers to replicate our study with a larger sample and to use another confirmatory statistical techniques like structural equations to test the robustness of our findings. 


\section{REFERENCES}

Barney,J.B, and Hansen, M.H., 1994. Trustworthiness as Source of Competitive Advantage, Strategic Management Journal, 15:175-190

Beck, L and I. Ajzen, 1991. Predicting Dishonest Actions Using Th Theory of Planned Behavior, Journal of Research in Personality, 25: 285-301

Bobek,D.D., Richard C Hatfield, 2003. An investigation of the Theory of Planned Behavior and the Role of Moral Obligation in Tax Compliance. Behavioral Research in Accounting, 15: 14-38

Carroll, John, 1987. Compliance With the Law, A Decision Making Approach to Taxpaying, Law and Human Behavior, 11:319 - 335.

Chan, K. Hung, and Phyllis L.L Mo, 2002. The Impact of Firm Characteristisc on BookTax-Conforming and Book-Tax-Difference Audit Adjustments. JATA, (Fall):18-34.

Djakfar, Muhammad, 2007. Agama, Etika, dan Ekonomi, Cetakan I, Penerbit UIN Malang Press

Etzioni, A. 1986. Tax evasion and perceptions of tax fairness: A Research Note, The Journal of Applied Behavioral Science, 22: 177-185.

Grasmick, H., N. Finley, and D. Glaser, 1984. Labor Force Participation, Sex-Role Attitude, and Female Crime: Evidence from a Survey of Adults" Social Science Quarterley 65. pp. 703-18.

Grasmick, H.G., and Scott, W.J., 1982. Tax Evasion and Mechanisms of social control. Journal of Economic Psychology, 2: 213-230.

Hite, Peggy A., and John Hasseldine, 2003. Tax Practitioner Credentials and the Incidence of IRS Audit Adjustments, Accounting Horizons: 1 -14

Jackson, B., V. Milliron, and D. Toy. 1986. Tax compliance research, findings, problems and Prospects, Journal of Accounting Literature: 125 -166.

Kaplan, S and P.M. Reckers, 1985. A Study of Tax Evasion Judgments, National Tax Journal, 38: 97 - 102

Keller, Carl Edward Jr., 1998. An experimental Investigation of How Ethical Orientations, Tax Rates, Penalty Rates, And Audit Rates Affect Tax Compliance Decisions, Dissertation, The University of Tennessee. 
Korsgaard, M., Schweiger, D., \& Sapienza, H. 1995. Building commitment, attachment, and trust in strstegic decision-making teams: The role of procedural justice. Academy of Management Journal, 38: 60-84.

Nam, Binh, Chris Evans, and Michael Walpole, 2002. Tax Compliance Costs: Research Methodology and Empirical Evidence From Australia. National Tax Journal. Vol LIII:229-252

Madeo, S., A. Schepanski, and W. Uecker. 1987. Modeling judgements of taxpayer compliance, The Accounting Review 62 (2): 323 - 342.

Magro, Anne, M., 1999. Contextual Features of Tax Decision Making Settings. JATA, 21: $63-73$

Mason, R., and L. Calvin, 1978. "A Study of Admitted Income Tax Evasion" Law and Society Review (Fall),pp. 73-89.

Mayer, R. C., Davis, J. H., Schoorman, F. D. 1995. An ingrative model of organizational trust, Academy of Management Review, 20: 709-734.

Minor, W. 1978. "Deterrence Research: Problems of Theory and Method" in Preventing Crime J.A. Cramer (Ed) (Beverly Hills:Sage), pp.21-45.

Reckers, P.M.J, D.L. Sanders and S.J. Roark, 1994. The Influence of Ethical Attitudes on Taxpayer Compliance, National tax Journal, 47: 825 - 836

Robbins,Stephen. P.,2001. Organizational Behavior. Ninth Edition, Ney York: Prentice Hall Inc.

Sanders, D. L. and R. W. Wyndelts. 1989. An Examination of tax practitioners decisions under uncertainty. Advances in Taxation: $41-72$.

Schadewald, M. 1989. Reference point effects in taxpayer decision making. The Journal of the American Taxation Association 10 (2): 69 - 84.

Smith, Ken G., Stephen J.Carroll, 1995. Intra and Interorganizational Cooperation: Toward A Research Agenda. Academy of Management Journal, Vol 38: 7-23

Spilker, Brian C., Ronald G. Worsham, and Douglas F.Prawitt, 1999. Tax Professional' Interpretations of Ambiguity in Compliance and Planning Decision Contexts, JATA 21 (Fall): $75-89$

Spicer, M. and S. Lundstedt. 1976. Understanding tax evasion, Public Finance 31 (2): 295 305. 
Tittle, C. 1980. Sanctions and Social Deviance: The Question of Deterrence. New York: Praeger.

Tridiatno, Agus,2000. Masalah - Masalah Moral, Penerbitan Universitas Atma Jaya Yogyakarta.

Westat Inc. 1980. Individual Income Tax Compliance Factors Study Qualitative Research, Prepared for the Internal Revenue Service, 4 February.

Wicks, Andrew.C., Shawn L Berman, Thomas M. Jones, 1999. The Structure of Optimal Trust: Moral and Strategic Implications. Academy of Management Review, Vol 24: 89 $-116$

Yankelovich, Skelly and White, Inc. 1984. Survey of Taxpayer Attitudes, Prepared for the Internal Revenue Service, December. 